\title{
AKTIVITAS OLAHRAGA DI MASA PANDEMI COVID-19 TERHADAP TINGKAT STRES MAHASISWA PENDIDIKAN OLAHRAGA UNIVERSITAS ISLAM KALIMANTAN MUHAMMAD ARSYAD AL BANJARI BANJARMASIN
}

\author{
Novri Asri ${ }^{1}$, Elsi Setiandari L. O. ${ }^{2}$ \\ Universitas Islam Kalimantan Muhammad Arsyad Al Banjari Banjarmasin ${ }^{1,2}$ \\ novriasri.na@gmail.com ${ }^{1}$, setianoctavia86@gmail.com²
}

\begin{abstract}
Abstrak
Permasalahan adaptasi baru yang dialami mahasiswa pada masa terjadinya pandemi COVID-19 merupakan penyebab stres yang paling umum terjadi pada saat ini, dimana Untuk mencegah penyebaran virus corona Pemerintah menerapkan kebijakan sosial dan physical distancing melalui Pembatasan Sosial Berskala Besar (PSBB). Menyikapi hal tersebut, Pemerintah akhirnya memutuskan untuk melaksanakan proses belajar mengajar melalui Daring. Berbagai strategi dalam manajemen stres juga dilakukan dalam mengurangi tingginyatingkat stres. Melakukan olahraga secara rutin dapat meningkatkan daya tahan tubuh DAN dapat mengurangi tingkat kejadian stres serta parahnya gangguan mood yang dialami mahasiswa selama terjadinya COVID-19. Tujuan Penelitian ini adalah untuk mengetahui hubungan antara kebiasaan olahraga di masa pandemi COVID19 dan stres yang terjadi pada mahasiswa Pendidikan Olahraga Universitas Islam Kalimantan Muhammad Arsyad Al Banjari Banjarmasin. Penelitian ini menggunakan desain penelitian analitik dengan menggunakan pendekatan cross-sectional. Pengambilan sampel secara accidental sampling, dengan jumlah sampel sebanyak 95 responden yang memenuhi kriteria inklusi dan eksklusi menggunakan uji Chi Square. Hasil uji statistik yang didapat yaitu terdapat hubungan yang bermakna antara kebiasaan berolahraga dengan stres sehingga dari analisis tersebut didapatkan hasil $p$-value sebesar 0,000 . Nilai p-value $<0,05$.

Kata Kunci:Olahraga, Stres, Covid-19
\end{abstract}

SPORTS ACTIVITIES DURING THE COVID-19 PANDEMIC AGAINST THE STRESS LEVEL OF STUDENTS OF SPORTS EDUCATION OF THE ISLAMIC UNIVERSITY OF KALIMANTAN MUHAMMAD ARSYAD AL BANJARI BANJARMASIN

\begin{abstract}
New adaptation problems experienced by students during the COVID-19 pandemic are the most common causes of stress at this time, where to prevent the spread of the coronavirus the Government implements social and physical distancing policies through Large-Scale Social Restrictions (PSBB). Responding to this, the Government finally decided to carry out the teaching and learning process through Online. Various strategies in stress management are also carried out in reducing high levels of stress. Doing exercise regularly can increase endurance AND can reduce the level of stress events and severe mood disorders experienced by students during the occurrence of COVID-19. The purpose of this research is to find out the relationship between sports habits during the COVID-19 pandemic and the stress that occurs in students of Sports Education, Islamic University of Kalimantan Muhammad Arsyad Al Banjari Banjarmasin. This research uses analytical research design using cross-sectional approach. Accidental sampling, with a total of 95 respondents who met the criteria of inclusion and exclusion using chi square

Correspondence author: Novri Asri, Universitas Islam Kalimantan Muhammad Arsyad Al Banjari Banjarmasin, Indonesia. E-Mail: novriasri.na@gmail.com

\section{(c) (i) (2)}

Jurnal HalamanOlahraga Nusantara licensed under a Creative Commons Attribution-ShareAlike 4.0 International License.
\end{abstract}


test. Statistical test results obtained that there is a meaningful relationship between exercise habits and stress so that from the analysis obtained p-value results of 0.000. P-value $<0.05$.

Keywords:Sports, Stress, Covid-19.

\section{PENDAHULUAN}

Dunia saat ini sedang mengalami pandemi dari wabah virus Corona. Perhimpunan Dokter Paru Indonesia (2020: iii) menyatakan Severe acute respiratory syndrome coronavirus 2 (SARS-CoV 2) adalah virus baru yang pertama kali dilaporkan di Kota Wuhan, Tiongkok Tengah dan telah menyebar ke beberapa negara. Kondisi ini meningkatkan kekhawatiran kasus corona dimana gejala ini mirip seperti SARS yang melanda Tiongkok hampir selama dua dekade lalu. Kasus mengenai coronavirus ini dilaporkan pertama kali yaitu pada tanggal 31 Desember 2019, di kota Wuhan. Coronavirus ini tidak lebih mematikan jika dibandingkan dengan Middle East Respiratory Syndrome (MERS) dan Severe Acute Respiratory Syndrome atau (SARS).

WHO akhirnya memberikan nama COVID-19 pada penyakit yang diakibat oleh coronavirus jenis baru tersebut. Deteksi 2019-nCoV sesuai dengan definisi operasional surveilans 2019- nCoV. Pertimbangkan 2019-nCoV sebagai etiologi ISPA berat. Semua pasien yang pulang ke rumahharus memeriksakan diri ke rumah sakit jika mengalami perburukan(Direktorat Jendral Pencegahan dan Pengendalian , 2020).Krisis kesehatan yang diakibatkan oleh wabah COVID-19 telah mempelopori pembelajaran online secara serempak. Tsunami pembelajaran online telah terjadi hampir di seluruh dunia selama pandemi COVID-19 (Goldschmidt \& Msn, 2020). Guru dan pendidik sebagai elemen penting dalam pengajaran diharuskan melakukan migrasi besar-besaran yang belum pernah terjadi sebelumya dari pendidikan tatap muka tradisional ke pendidikan online atau pendidikan jarak jauh(Bao, 2020).

Menyikapi hal tersebut, Pemerintah akhirnya meliburkan para siswa dan mahasiswa untuk tidak bersekolah, perkuliahan ataupun memberlakukan aturan untuk bekerja di dalam rumah. Karena hal tersebut, untuk tetap selalu menjaga kebugaran tubuh dan tetap terhindar dari Covid-19, maka para siswa dan 
mahasiswa diharuskan untuk tetap beraktivitas sehari-hari dengan melakukan olahraga. Menurut (WHO, 2017)aktivitas fisik didefinisikan sebagai gerakan tubuh yang dihasilkan oleh otot rangka yang memerlukan pengeluaran energi. Meningkatkan pengeluaran tenaga dan energi (pembakaran kalori). Aktivitas fisik pada remaja dapat mempunyai hubungan dengan peningkatan rasa percaya diri, self-concept, rasa cemas dan stress yang rendah(Brown, 2013).

Permasalahan yang sering dihadapi yaitu pada kalangan mahasiswa menjadi kurang antusias dan malas untuk melakukan olahraga secara aktif (melibatkan motorik kasar). Mahasiswa biasanya lebih tertarik untuk melakukan permainan elektronik seperti game online, gadget maupun game-game elektronik lainnya. Mereka merasa sangat nyaman untuk memainkan game tersebut tanpa merasakan kebosanan dan kejenuhan dengan jangka waktu yang lama. Penggunaan smartphone ternyata juga membawa dampak negatif bagi perkembangan mahasiswa selama kondisi libur seperti ini, yang ditandai dengan malasnya mahasiswa dalam melakukan aktivitas gerak dan berinteraksi (Triansyah \& Gustian, 2020).

Hal ini menjadikan waktu untuk bermain dengan teman sebaya menjadi sangat berkurang dan terjadi perubahan pola hidup mahasiswa yang sebelumnya banyak bergerak menjadi sedikit gerak atau berdiam diri. Fenomena seperti ini akan menyebabkan terjadinya gangguan metabolisme pada tubuh sehingga terjadinya penurunan kesegaran jasmani, kesehatan, kelebihan berat badan atau obesitas, keterampilan, serangan jantung, diabetes, dan bahkan mempengaruhi kapasitas, kreativitas, emosional, sosial, dan kecerdasan (Wicaksono \& Nurhayati, 2013).

Menurut (Joko, 2011), lahraga yang cukup dapat membantu mengurangi ketegangan anda. Berolahraga membantu anda lebih sehat, meningkatkan energi dan stamina anda, membuat pikiran lebih fresh, dan membuat tidur lebih pulas.Melakukan kegiatan aktivitas fisik seperti berolahraga sangatlah besar manfaatnya bagi tubuh dan pikiran. Melakukan olahraga secara rutin dapat 
mengurangi tekanan darah tinggi, membantu mengelola berat badan serta mengurangi resiko penyakit jantung, stroke dan diabetes.

Olahraga yang teratur juga mampu meningkatkan kesehatan mental dan dapat mengurangi risiko depresi, penurunan kognitif, dan menunda timbulnya demensia, serta meningkatkan perasaan kesejahteraan secara keseluruhan. Mahasiswa yang memiliki ketergantungan terhadap media digital cenderung lebih banyak melakukan aktivitas menetap, mereka terlihat lebih banyak duduk dibandingkan dengan berjalan-jalan atau bermain di lapangan bersama teman lainnya. Menurut (Mutaqin, 2018)Oleh sebab itu untuk menyiasati agar anak-anak tidak hanya menyukai permainan elektronik yang hanya mampu memenuhi aspek psikis anak, perlu dibentuk suatu alternatif agar anak juga memiliki kegemaran serta minat dalam berolahraga. Olahraga tersebut harus memiliki daya tarik untuk selalu dimainkan oleh anak dan mampu membuat anak senang serta termotivasi untuk memainkannya.

Penggunaan smartphone juga membawa dampak negatif bagi perkembangan siswa yang ditandai dengan malasnya siswa dalam melakukan aktivitas gerak dan berinteraksi(Triansyah \& Gustian, 2020). Hal ini menjadikan waktu bermain dengan teman sebaya menjadi berkurang dan terjadi perubahan pola hidup siswa yang dari banyak bergerak menjadi sedikit gerak atau berdiam diri. Penomena ini akan menyebabkan terjadinya gangguan metabolisme tubuh sehingga terjadi penurunankesegaran jasmani, kesehatan, kelebihan berat badan atau obesitas, keterampilan, serangan jantung, diabetes, dan bahkan mempengaruhi kapasitas, kreativitas, emosional, sosial, dan kecerdasan (Wicaksono \& Nurhayati, 2013).

Berdasarkan hasil wawancara dengan beberapa mahasiswa khususnya pada mahasiswa pendidikan olahraga, ketika mereka menjawab pertanyaan yang di ajukan yaitu "apakah anda suka memainkan game online setiap hari melalui handphone dan apakah anda tidak bosan memainkan game tersebut?“". Diperoleh keterangan bahwa sebagian besar mahasiswa sering memainkan game online melalui smartphone mereka masing-masing setiap hari baik itu di saat siang, sore 
maupun malam. Bagi mereka bermain game online merupakan salahsatu cara menghabiskan waktu berjam-jam yang dilakukan tanpa mengenal bosan.Apalagi dengan dukungan fitur, taktik serta tim saat bermainmembuat seseorang tentu tidak akan pernah ingin meninggalkan permainan tersebut.

Di masa pandemi seperti ini, penggunaan internet sudah menjadi hal yang biasa bagi kalangan remaja. Remaja rela untuk duduk berjam-jam menghabiskan waktu di depan komputer maupun hp. Hal ini cenderung menimbulkan kurangnya olahraga dan durasi tidur yang cukup khususnya bagi remaja, selain itu juga makanan yang dikonsumsi tidak begitu diperhatikan karena terlalu fokus dan asik dengan bermain game sehingga asupan gizi yang masuk menjadi berkurang. Remaja yang kurang melakukan olahraga sehari-hari menyebabkan tubuhnya menjadi kurang mengeluarkan energi ditambah dengan asupan gizi yang kurang maka seorang remaja akan menjadi lebih rentan dengan masalah gizi.

Aktivitas fisik memiliki berbagai macam manfaat, diantaranya adalah mengendalikan berat badan, mengurangi risiko penyakit kardiovaskular, mengurangi risiko diabetes tipe 2 dan sindrom metabolic, mengurangi risiko beberapa jenis kanker, memperkuat tulang dan otot serta memperbaiki kesehatan mental. Olahraga rutin yang dilakukan sehari-hari dapat meningkatkan daya tahan tubuh sehingga menekan reaksi peradangan yang berlebihan. Rutin beraktivitas olahraga untuk mengontrol penyakit pemberat Covid-19, olahraga juga dapat mengurangi resiko stres yang banyak dialami ketika wabah pandemi COVID-19 ini. Olahraga bisa dilakukan di lingkungan sendiri dan hasilnya akan efektif asalkan dilakukan secara teratur, terukur dan senang hati. Jasper menuturkan, setelah 25 menit, maka mood orang yang berolahraga akan lebih baik, stres berkurang dan akan merasakan energi tubuh yang lebih.

Menurut (Yuli, 2010)berbagai penelitian menyebutkan bahwa olahraga merupakan salah satu cara melepasstres yang efektif. Selama berolahraga tubuh kita menghasilkan enzim yang disebutendorphin, satu jenis morfin alami yang memicu rasa senang dan rileks. Olahraga adalahfaktor penting dalam rumus pola hidup sehat.Tekanan dari lingkungan atau orang lain (eksternal), misalnyasikap 
teman kerja yang tidak kooperatif, pekerjaan terlalu banyak, tempat tinggal yang tidak nyaman dan lain-lain. (Zenko, 2021).

Selain itu, stres dapat menjadi penyebab timbulnya masalah serius terhadap kesehatan dan emosional. Mencari cara untuk mengelola stres adalah bagian yang penting untuk menjaga diri kita sendiri. Melakukan olahraga secara teratur untuk kebugaran merupakan salah satu cara terbaik untuk mengurangi stres. (Astari, 2009)mengatakan bahwa berolahraga teratur dapat membuat anda lebih tahan terhadap stres, bahkan depresi. Pasalnya, dengan melakukan olahraga yang cukup takarannya dapat meningkatkan kadar endorphin dalam tubuh. Hormon ini dapat memperbaiki suasana hati, yang membantu mengatasi dan mencegah stres. Saat anda berolahraga, tubuh mengeluarkan beta-endorphins yang menangkal hormon stres yang menjalar ke tubuh. Sehingga kita mendapati perasaan nyaman dan menyenangkan sehabis berolahraga.

\section{METODE}

Penelitian ini termasuk penelitian analitik karena menganalisis dinamika korelasi antara variabel bebas dan variabel terikat. Model pendekatan yang digunakan pada penelitian ini adalah pendekatan secara cross sectional, dimana dinamika korelasi dikumpulkan dengan cara pendekatan atau pengumpulan data sekaligus pada suatu saat (point time approach). Peneliti melakukan penelitian pada mahasiswa Program Studi Pendidikan Olahraga yang berlokasi di Universitas Islam Kalimantan Muhammad Arsyad Al Banjari Banjarmasin pada tanggal 10 November 2020 dengan jumlah sampel sebanyak 95 responden. yang memenuhi kriteria inklusi dan eksklusi.Dalam penelitian ini pengambilan sampel secara accidental sampling, Variabel independen pada penelitian ini adalah kebiasaan berolahraga, sedangkan variabel dependennya adalah pencegahan COVID-19.

Data dikumpulkan melalui kuesioner yang dibagikan kepada para responden. Sebelumnya responden diberikan penjelasan tentang cara pengisian, tujuan dari kuesioner dan disertai petunjuk pengisian kuesioner. Pengolahan data 
dilakukan dengan menggunakan program komputer. Analisis data dibagi menjadi dua, yaitu analisis univariat dan analisis bivariat menggunakan uji Chi Square(Notoatmodjo, 2010).

\section{HASIL DAN PEMBAHASAN}

Subyek dalam penelitian ini adalah mahasiswa Pendidikan Olahraga Universitas Islam Kalimantan Muhammad Arsyad Al Banjari Banjarmasin berdasarkan data yangdiperoleh dan yang memenuhi kriteria inklusi dan eksklusi istilah Pembatasan Sosial Berskala Besar (PSBB).

Tabel 1 Rangkuman Hasil Karakteristik Umum Responden Penelitian

\begin{tabular}{clcc}
\hline No & \multicolumn{1}{c}{ Keterangan } & Frekuensi Absolut & Frekuensi Relatif \\
\hline 1 & Jenis Kelamin & & \\
\hline Laki-laki & 63 & 66,3 \\
\hline Perempuan & 32 & 33,6 \\
\hline 2 & Olahraga & & 68,4 \\
\hline & Rutin Berolahraga & 65 & 31,6 \\
\hline & Tidak Rutin Berolahraga & 30 & \\
\hline 3 & Stres & & 46,3 \\
\hline & Ya & 44 & 53,7 \\
\hline & Tidak Jumlah & 51 & $\mathbf{1 0 0}$ \\
\hline & $\mathbf{9 5}$ &
\end{tabular}

Sumber : Data primer yang diperoleh 2020

Berdasarkan tabel 1.1 dapat diketahui bahwa responden yang mengalami stres sebanyak 65 orang atau $68,4 \%$ dan yang tidak mengalami stres hanya berjumlah 30 orang atau 31,6\%. Berdasarkan tabel 1.1 dapat diketahui bahwa Olahraga dibagi dalam dua kategori, yaitu Rutin Berolahraga dan tidak rutin berolahraga. Hasil penelitian tersebut menjelaskan bahwa sebagian besar responden melakukan olahraga yang tidak rutin yaitu sebanyak 51 orang atau $53,7 \%$ dan hanya 44 orang atau $46,3 \%$ yang rutin berolahraga.

Tabel2 Rangkuman Kebiasaan Berolahraga Terhadap Tingkat Stres

\begin{tabular}{cccc}
\hline Variabel & Stres & $\mathrm{P}$ & Keterangan \\
Rutin Berolahraga & 44 & 0,000 & Signifikan \\
\hline
\end{tabular}


Berdasarkan tabel 2 dapat diketahui bahwa dari 44 responden yang yang rutin berolahraga dan dari 51 responden yang tidak berolahraga. Dari seluruh responden didapatkan hasil bahwa lebih banyak yang tidak rutin melakukan olahraga yang mengalami stres. Mengingat tidak ada sel yang memiliki nilai expected count $<5$, maka digunakan uji Continuity Correction dengan $\alpha=0,05$ sehingga dari analisis tersebut didapatkan hasil p-value sebesar 0,000. Nilai pvalue $<0,05$ artinya bahwa ada hubungan antara olahraga dengan stres.

\section{PEMBAHASAN}

\section{a. Gambaran Kebiasaan Berolahraga}

Dari hasil penelitian menunjukkan bahwa sebagian besar responden mengalami stres sebanyak 65 orang $(68,4 \%)$ dan yang tidak stres sebanyak 30 orang $(31,6 \%)$. Hal ini dapat disebabkan karena mahasiswamempunyai waktu luang untuk belajar dan berada di rumah karena adanya himbauan dari Pemerintah untuk melaksanakan proses belajar mengajar daring sehingga mengharuskan mahasiswa untuk libur tidak melakukan tatap muka dalam belajar selama terjadinya pandemi COVID-19. Penelitian ini sesuai dengan penelitian Karlina (2011) yang mengatakan 54,4\% mahasiswa tingkat persiapan bersama di Institut Pertanian Bogor memiliki kebiasaan berolahraga yang buruk. Olahraga rutin memiliki banyak manfaat bagi tubuh seperti mencegah penyakit, menjaga berat badan, dan menurunkan stres. Seseorang yang berolahraga akan terlihat lebih rileks dan ceria karena ketika berolahraga tubuh menghasilkan hormon endorfin yang memicu rasa senang dan nyaman dalam tubuh.

\section{b. Gambaran Stres}

Dari hasil penelitian menunjukkan bahwa sebagian besar responden yang tidak stres sebanyak 51 orang $(53,7 \%)$ dan yang stres sebanyak 44 orang (46,3\%).Data tersebut menunjukkan bahwa tingkat stres pada mahasiswa pendidikan olahraga Universitas Islam Kalimantan Muhammad Arsyad Al Banjari 
Banjarmasin cukup tinggi. Hal ini dapat terjadi karena mahasiswa harus mengalami proses adaptasi terhadap proses belajar mengajar yang baru secara daring selama terjadinya pandemi COVID-19,mempertahankan dalam memperoleh dan mempertahankan prestasi akademik, dan juga keadaan tempat tinggal yang berbeda yang membuat kendala dalam belajar secara daring yang membuat stres mahasiswa karena tidak bisa mengikuti sepenuhnya proses belajar mengajar yang biasanya dilakukan di lapangan.Sesuai dengan penelitian (Suganda, 2014) yang mengatakan bahwa mahasiswa tahun pertama di Fakultas Kedokteran Universitas Sumatera Utara memiliki tingkat stres yang cukup tinggi, dan tingkat stres terbanyak pada tingkat stres sedang yaitu $86,5 \%$.

Penelitian ini juga menunjukkan stressor yang dapat menyebabkan stres yang paling banyak pada mahasiswa pendidikan olahraga Universitas Islam Kalimantan Muhammad Arsyad Al Banjari Banjarmasin adalah stresor terkait dengan akademik dan terkait hubungan belajar-mengajar secara daring selama pandemi COVID-19. Hal ini didapat dengan menghilangkan jumlah stres ringan pada responden di setiap stresor. Menurut(Yusoff \& Rahim, 2010), stres ringan dapat dikatakan sebagai keadaan tidak stres karena tidak menimbulkan efek berbahaya atau dapat diatasi oleh tubuh.

Indikasi yang palingdominan yaitu pada butir pernyataan "Bagaimana anda mengisi waktu luang di rumah agar tidak stres dalam mengikuti pelajaran daring ?" banyak dari mahasiswa yang menjawab "saya mengisi waktuluang di rumah dengan bermain game online pada smartphone, karena merasa bosan dan stres pada saat belajar mengajar secara daring seperti ini”. Data yang peneliti dapatkan dari wawancara terhadap gangguan kesehatan yaitu : dari 33 mahasiswa yang menyatakan frekuensi sakit kepala sebanyak 45 mahasiswa, yang menyatakan sakit mata sebanyak 20 mahasiswa, yang merasa pegal kecapean sebanyak 28 mahasiswa dan yang menyatakan sakit maagFrekuensi jumlahnya sebanyak 14 mahasiswa. Banyak jumlahmahasiswa yang menyatakan terjadi gangguan terhadap kesehatan berupa sakit kepalaataupun gangguan terhadap penglihatan, pegal kesemutan dan sakit maag. Hal ini diakibatkan karena mereka 


\section{OLAHRAGA}

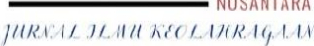

Jendral A. Yani Street Lorong Gotong Royong 9/10 Ulu Palembang South Sumatera

email jurnal: jurnalhon@univpgri-palembang.ac.id situs web: http://www.univpgri-palembang.ac.id

\section{Accredited}

SINTA 3

banyak menunda waktu makan dan asik bermain game terus sampai lupa waktu bahkan begadang.Dari hasil wawancara banyak siswa yang jarang berolah raga akibat lebih senang bermain gamedaripada melakukan olahraga. Dampak pengaruh ke otak kadang mereka sulit konsentrasi dan menimbulkan stres.

Stresor lain yang dapat menyebabkan stres pada responden yang paling banyak yaitu stresor terkait hubungan belajar-mengajar. Berdasarkan jawaban kuesioner, stres ini terjadi karena banyaknya materi pelajaran yang harus dipelajari secara daring dan tidak langsung dilakukan praktek serta kendala jaringan yang dialami karena faktor cuaca dan berbeda-beda daerah tempat tinggal mahasiswa, kurangnya feedback yang diberikan dosen, kualitas dosen yang mengajar, serta banyaknya tugas yang diberikan dosen. Sesuai dengan penelitian (Al-Dabal, Koura, Rasheed, \& Al-Sowielem, 2010)di Arab Saudi yang mengatakan bahwa metode mengajar dan lingkungan belajar merupakan salah satu penyebab stres bagi mahasiswa kedokteran.

Berdasarkan hasil penelitian menunjukkan bahwa stres terkait akademik dan stres terkait hubungan belajar-mengajar menjadi stressor yang paling banyak menyebabkan stres pada responden. Hal ini dapat disebabkan karena perbedaan sistem belajar yang baru dimana lebih banyak berada di rumah yang menjadi penyebab terbanyak kejadian stres pada mahasiswa. Hal ini dikaitkan dengan proses adaptasi dan kesulitan dalam menghadapi ujian serta sedikitnya waktu untuk persiapan diri menghadapi ujian dimana terbiasa belajar di lapangan dan ujian di lapangan.(Sharif, 2007).

Hasil penelitian ini diperoleh hasil nilai $\mathrm{P}$ value sebesar $0,000(\mathrm{p}<0,05)$, yang menunjukkan bahwa terdapat hubungan yang bermakna antara kebiasaan berolahraga dengan stres pada mahasiswa pendidikan olahraga Universitas Islam Kalimantan Muhammad Arsyad Al Banjari Banjarmasin. Hal ini sesuai dengan teori yang mengatakan bahwa olahraga rutin dapat menurunkan stres. Hasil penelitian ini juga sesuai dengan penelitian (Akandere, 2002). yang menyatakan bahwa terdapat hubungan yang bersifat inversi antara olahraga dengan tingkat 


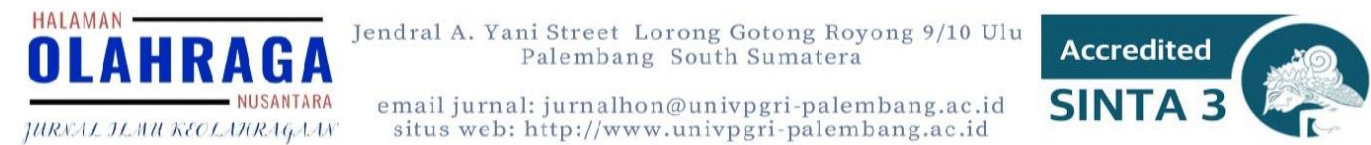

kecemasan, yang berarti olahraga dapat menurunkan stres yang dapat menimbulkan kecemasan dan depresi.

Hal ini terkait dengan penurunan hormon-hormon stres saat berolahraga. Olahraga rutin dapat menurunkan kadar hormon epinefrin dan kortisol. Hormonhormon tersebut yang disebut juga sebagai hormon stres akan meningkat saat tubuh menghadapi suatu stresor. Saat seseorang berolahraga maka tubuh akan memproduksi beta-endorfin yang memiliki efek memperbaiki suasana hati sekaligus menurunkan hormon kortisol dalam tubuh (Sundari, 2012).

Stres dapat memicu gangguan mood pada individu. Namun, tidak semua individu yang dihadapkan stresor yang sama akan mengalami gangguan mood Menurut(Rasmun, 2004)respon stres terhadap individu berbeda-beda tergantung pada beberapa hal, yaitu kemampuan individu mempersepsikan stresor, intensitas stressor yang dialami, jumlah stressor yang dihadapi dalam waktu yang sama, lamanya paparan stressor terhadap individu, pengalaman masa lalu terhadap stresor yang sama, dan tingkat perkembangan individu. Banyak dampak negatif yang dapat ditimbulkan oleh stres apabila tidak ditangani dengan baik. Oleh karena itu, perlu strategi khusus untuk menanggulangi efek negatif terhadap stres, salah satunya dengan rutin berolahraga(Gunarya, Tamar, \& Ibnu, 2011).

\section{KESIMPULAN}

Berdasarkan hasil penelitian yang diperoleh dapat disimpulkan yaitu : Kebiasaan berolahraga pada mahasiswa Pendidikan olahraga Universitas Islam Kalimantan Muhammad Arsyad Al Banjari Banjarmasin yaitu sebagian besar responden melakukan olahraga yang tidak rutin sebanyak 51 Mahasiswa dan hanya 44 Mahasiswa yang rutin berolahraga. Tingkat stres pada mahasiswa pendidikan olahraga Universitas Islam Kalimantan Muhammad Arsyad Al Banjari Banjarmasin yang mengalami stres sebanyak 65 Mahasiswa dan yang tidak mengalami stres hanya berjumlah 30 Mahasiswa. Diharapkan kepada mahasiswa Pendidikan Olahraga Universitas Islam Kalimantan Muhammad Arsyad Al Banjari Banjarmasin untuk tetap melakukan olahraga minimal 3 kali dalam 
seminggu dengan durasi waktu sekitar 30 menit walaupun disaat masa pandemi COVID-19. Olahraga yang dilakukan adalah untuk menjaga kesehatan jasmani sekaligus juga untuk menjaga kesehatan rohani serta diharapkan juga dapat memanajemen stres yang dihadapi sehingga terhindar dari stres yang sangat merugikan dan juga dapat menimbulkan penyakit psikiatri yaitu seperti keadaan depresi. Selain itu bagi orang tua diharapkan dapat memberikan waktu luang bersama anak- anak dandapat membantu serta memantau anak-anaknya ketika melakukan pembelajaran daring di rumah agar mampu mengontrol waktu untuk bermain, berolahraga dan untuk belajar.

\section{DAFTAR PUSTAKA}

Akandere, M. T. (2002). The effect of physical exercise on anxiety. Sport Journal. United States Sports Academy.

Al-Dabal, B. K., Koura, M. R., Rasheed, P., \& Al-Sowielem. (2010). A comparative Study of Perceived Stress Among Female Medical And NonMedical University Students In Dammam. SQU Medical Journal, 231.

Astari, K. (2009). Olahraga untuk Meredam Stres. http://staffnew.uny.ac.id/, 1-8.

Bao, W. (2020). COVID-19 and online teaching in higher education . A case study of Peking University, 113-115.

Brown. (2013). Nutrition through the life cycle. Wadsworth: USA.

D. P. (2020). Direktorat Jendral Pencegahan dan Pengendalian Penyakit.

Goldschmidt, K., \& Msn, P. D. (2020). The COVID-19 pandemic: Technology use to support the wellbeing of children. Journal of Pediatric Nursing, 3-5.

Gunarya, A., Tamar, M., \& Ibnu, I. F. (2011). Bersahabat dengan stres. Makasar.

Joko, S. (2011). 8 Tips Management Stres dengan Mengatur Keseimbangan Pola Hidup Anda.

Mutaqin, L. U. (2018). Upaya meningkatkan kebugaran jasmani melalui circuit training. Jurnal Pendidikan Jasmani Indonesia, 1-10.

Notoatmodjo, S. (2010). Promosi Kesehatan Teori dan Aplikasi. Jakarta: Rineka Cipta.

Rasmun. (2004). Stres, Koping dan Adaptasi. Jakarta: Sagung Seto. 
Sharif, S. K. (2007). Stress and coping strategies among medical students in Basrah. Medical Journal of Basrah University, 28-32.

Suganda. (2014). Tingkat Stress pada Mahasiswa Tahun Pertama Fakultas Kedokteran Universitas Sumatera Utara angkatan 2013. Fakultas Kedokteran Universitas Sumatera Utara, 10.

Sundari, J. (2012). Hubungan antara tingkat stres dan intensitas olahraga pada mahasiswa reguler 2008 Fakultas Matematika dan Ilmu Pengetahuan Alam Universitas Indonesia. Depok: Fakultas Ilmu Keperawatan Universitas Indoesia.

Triansyah, A., \& Gustian, U. (2020). Penggunaan permainan tradisional untuk meningkatkan keterampilan gerak fundamental siswa Sekolah Dasar. Jurnal Pendidikan Jasmani Indonesia, 78-91.

WHO. (2017). Physical activity. World Health Organization.

Wicaksono, I. D., \& Nurhayati, F. (2013). Survey Kemampuan Motorik Siswa Sekolah Dasar Muhammadiyah Kelas IV Se-Kecamatan Taman Sidoarjo Tahun Ajaran 2012-2013. Jurnal Pendidikan Olahraga dan Kesehatan, 98-103.

Yuli. (2010). Atasi Stres dengan Olahraga. http://staffnew.uny.ac.id/, 1-8.

Yusoff, M., \& Rahim, A. (2010). The medical student stressor questionnaire (MSSQ) manual. Kelantan: KKMED.

Zenko. (29. Januari 2021). Cara Mudah Mengatasi Masalah Stres Anda. Dostupné na Internete: Huge Domains: https://www.hugedomains.com/domain_profile.cfm?d=sahabatwanita\&e= com 